\title{
Awareness regarding reproductive tract infections among married women in the rural area of Surendranagar
}

\author{
Komal P. Thekdi ${ }^{1 *}$, Prakash Mehta ${ }^{2}$, Pukur I. Thekdi ${ }^{3}$
}

\begin{abstract}
${ }^{1}$ Department of Preventive and Social Medicine, C U Shah Medical College, Surendranagar - 363001, Gujarat, India
${ }^{2}$ Department of Psychiatry, C U Shah Medical College, Surendranagar - 363001, Gujarat, India

${ }^{3}$ Department of Surgery, C U Shah Medical College, Surendranagar - 363001, Gujarat, India
\end{abstract}

Received: 11 December 2013

Accepted: 15 December 2013

\section{*Correspondence:}

Dr. Komal P. Thekdi,

E-mail: drkomalthekdi@gmail.com

(C) 2014 Thekdi KP et al. This is an open-access article distributed under the terms of the Creative Commons Attribution Non-Commercial License, which permits unrestricted non-commercial use, distribution, and reproduction in any medium, provided the original work is properly cited.

\begin{abstract}
Background: High levels of gynaecological morbidity, especially reproductive tract infections and sexually transmitted infections may turn out to be fatal if not treated properly. The objectives of this study were basic awareness about disease and association with socio-economic findings, awareness regarding disease occurrence and transmission, symptoms, complications of disease; HIV prevention.

Methods: Various community based studies carried out in the different regions world showed the prevalence of reproductive tract infections $36-84 \%$. The sample size of study as per statistical calculation $\left(4 p q / l^{2}\right.$, where $p=50, q=$ $100-p$ and $1=10 \%$ of $p$ ) came out to be 400 . Method of sampling - Prior enlisting all villages of Surendranagar district, one village was selected randomly.

Results: Basic awareness about disease was $64.0 \%$; $82.2 \%$ of women narrated symptoms. $42.00 \%$ of women had no idea regarding its complications. Knowledge regarding HIV prevention was $59.50 \%$.

Conclusions: Effective strategies for the early diagnosis and treatment should be made.
\end{abstract}

Keywords: Awareness, Disease occurrence and transmission, HIV prevention

\section{INTRODUCTION}

High levels of gynaecological morbidity, especially reproductive tract infections and sexually transmitted infections may turn out to be fatal if not treated properly. ${ }^{1}$

Reproductive tract infections generally seen as a silent epidemic can have severe consequences including infertility, ectopic pregnancy, chronic pelvic pain, miscarriage, neonatal blindness, increased risk of HIV infection and even death. ${ }^{2}$

\section{Aims and objectives}

To assess the awareness about Reproductive Tract Infections and its association with socio-economic details, to find out the knowledge regarding disease occurrence and transmission, symptoms, complications and HIV prevention.

\section{METHODS}

\section{Sample size}

Various community based studies carried out in the different regions world showed the prevalence of reproductive tract infections 36-84\%. Based on the prevalence derived from pilot study carried out among married women of reproductive age group in this area, the prevalence was found $50 \%$; the sample size of study as per statistical calculation $\left(4 \mathrm{pq} / \mathrm{l}^{2}\right.$, where $\mathrm{p}=50, \mathrm{q}=$ $100-\mathrm{p}$ and $\mathrm{l}=10 \%$ of $\mathrm{p}$ ) came out to be 400 . 


\section{Method of sampling}

Prior enlisting all villages of Surendranagar district, one village was selected randomly. After random selection the village found was Khodu.

The houses in area were listed and a randomly selected house was taken as the first house to be surveyed.

\section{RESULTS}

Table 1 shows that basic awareness about disease was $64.0 \%$. There was a significant association between age group and awareness $(\chi 2=6.549$, D.F. $=2, \mathrm{P}$ value $=$ $0.037)$, A significant association found with educational status of women and awareness about the disease $(\chi 2=$ 6.549$, D.F. $=5, \mathrm{P}$ value $=0.0417) . \mathrm{A}$ significant association with socio-economic class and awareness was also found $(\chi 2=14.45$, D.F. $=4, \mathrm{P}$ value $=0.006)$.

Table 1: Awareness regarding reproductive tract infections and its association with the socio-economic details amongst study group $(\mathrm{N}=400)$.

\begin{tabular}{|c|c|c|c|}
\hline $\begin{array}{l}\text { Socio- } \\
\text { economic } \\
\text { details }\end{array}$ & $\begin{array}{l}\text { Frequency } \\
(\mathrm{N}=400) \\
\text { (Percentage) }\end{array}$ & $\begin{array}{l}\text { Awareness } \\
\text { (Frequency) }\end{array}$ & \\
\hline \multicolumn{4}{|c|}{ 1. Age group } \\
\hline $15-24$ yrs & $145(36.3 \%)$ & 91 & \multirow{4}{*}{$\begin{array}{l}\chi 2=6.549 \\
\text { D.F. }=2, \\
P \text { value }= \\
0.0379\end{array}$} \\
\hline $25-34$ yrs & $186(46.5 \%)$ & 138 & \\
\hline $35-44$ yrs & $69(17.2 \%)$ & 27 & \\
\hline Total & $400(100 \%)$ & $256(64 \%)$ & \\
\hline
\end{tabular}

\section{Education of women}

\begin{tabular}{|c|c|c|c|}
\hline \\
\hline Illiterate & $126(31.5 \%)$ & 51 & \multirow{7}{*}{$\begin{array}{l}\chi 2=6.549 \\
\text { D.F. }=5 \\
\text { P value }= \\
0.0417\end{array}$} \\
\hline $\begin{array}{l}\text { Primary } \\
\text { school }\end{array}$ & $135(33.8 \%)$ & 94 & \\
\hline $\begin{array}{l}\text { Secondary } \\
\text { school }\end{array}$ & $62(15.4 \%)$ & 47 & \\
\hline $\begin{array}{l}\text { Higher } \\
\text { secondary }\end{array}$ & $38(9.5 \%)$ & 33 & \\
\hline $\begin{array}{l}\text { Intermediate/ } \\
\text { Diploma }\end{array}$ & $9(2.3 \%)$ & 6 & \\
\hline $\begin{array}{l}\text { Graduate and } \\
\text { above }\end{array}$ & $30(7.5 \%)$ & 25 & \\
\hline Total & $400(100 \%)$ & $256(64 \%)$ & \\
\hline \multicolumn{4}{|c|}{ 3. Socio-economic class } \\
\hline Class I & 24 & 20 & \multirow{6}{*}{$\begin{array}{l}\chi 2=14.45 \\
\text { D.F. }=4 \\
P \text { value = } \\
0.006\end{array}$} \\
\hline Class II & 46 & 37 & \\
\hline Class III & 62 & 52 & \\
\hline Class IV & 118 & 93 & \\
\hline Class V & 150 & 62 & \\
\hline Total & $400(100 \%)$ & $256(64 \%)$ & \\
\hline
\end{tabular}

Table 2 shows that not only the educational status of women but even I.Q. status is also associated with the awareness about the disease $(\chi 2=8.75$, d.f. $=1$, $\mathrm{P}$ value $=$ 0.003 , statistically significant).
Table 2: IQ score of women in association with awareness of reproductive tract infections (By clinical interview taken by a qualified psychiatrist).

\begin{tabular}{|lll|}
\hline $\begin{array}{l}\text { IQ } \\
\text { score }\end{array}$ & $\begin{array}{l}\text { Basic } \\
\text { awareness } \\
\text { yes } \\
\text { (Frequency) }\end{array}$ & $\begin{array}{l}\text { Basic } \\
\text { awareness } \\
\text { no } \\
\text { (Frequency) }\end{array}$ \\
\hline$<90$ & 117 & 88 \\
\hline$\geq 90$ & 139 & 56 \\
\hline Total & 256 & 144 \\
\hline $\begin{array}{l}\chi 2=8.75, \text { d.f. }=1, \text { P value }=0.003 \\
\text { statistically significant }\end{array}$ \\
\hline
\end{tabular}

Table 3 shows that knowledge regarding disease occurrence and transmission among study population was only $35.50 \% ; 8.5 \%$ replied about lack of personal hygiene, followed by $6.0 \%$ women who told infection was the main reason. $5.3 \%$ about sexual intercourse followed by $4.0 \%$ of women who gave the reason that multiple sexual partners as the main culprit for the same.

Table 3: Knowledge regarding disease occurrence and transmission amongst study group $(\mathrm{N}=400)$.

\begin{tabular}{|lll|}
\hline $\begin{array}{l}\text { Knowledge regarding disease } \\
\text { occurrence and transmission }\end{array}$ & Frequency & $\%$ \\
\hline No idea & 258 & 64.5 \\
\hline Lack of personal hygiene & 34 & 8.5 \\
\hline Sexual intercourse & 21 & 5.3 \\
\hline Infections & 24 & 6.0 \\
\hline Multiple sexual partners & 16 & 4.0 \\
\hline Multiple responses & 22 & 5.5 \\
\hline $\begin{array}{l}\text { Lack of personal hygiene, } \\
\text { infections }\end{array}$ & 14 & 3.5 \\
\hline $\begin{array}{l}\text { Lack of personal hygiene, } \\
\text { sexual intercourse }\end{array}$ & 8 & 2.0 \\
\hline $\begin{array}{l}\text { Lack of personal hygiene, } \\
\text { infections, sexual intercourse }\end{array}$ & 3 & 0.8 \\
\hline $\begin{array}{l}\text { Lack of personal hygiene, } \\
\text { infections, sexual intercourse, } \\
\text { multiple sexual partners }\end{array}$ & 3 & \\
\hline
\end{tabular}

Table 4 shows that out of 400 women; knowledge about symptoms $17.8 \%$ having no idea; $15.8 \%$ women gave low backache was the main symptom; $11.5 \%$ narrated vaginal discharge, $10.5 \%$ of women reported itching in the private part. $5.8 \%$ of women reported lower abdominal pain; $5.3 \%$ of women gave burning micturition. $3.0 \%$ of women reported dyspareunia whereas only $1.0 \%$ of women reported genital ulcerations.

Table 5 shows that regarding HIV prevention and transmission among study population was $59.50 \% .21 .5 \%$ reported that usage of condoms was the possible way of prevention of HIV followed by $11.75 \%$ told treatment of cases and their partners, $8.50 \%$ of women narrated monogamous relationships, $8 \%$ about usage of sterile 
needle was the way of prevention and transmission of HIV.

Table 4: Knowledge regarding complications of reproductive tract infections amongst study group $(\mathrm{N}=400)$.

\begin{tabular}{|lll|}
\hline $\begin{array}{l}\text { Knowledge regarding } \\
\text { complications of reproductive } \\
\text { tract infections }\end{array}$ & Frequency & $\%$ \\
\hline No idea & 168 & 42.00 \\
\hline Cancer & 31 & 7.75 \\
\hline Abortion & 23 & 5.75 \\
\hline Pre-term labor & 14 & 3.50 \\
\hline Premature rupture of membrane & 8 & 2.00 \\
\hline Dysmenorrhoea & 43 & 10.75 \\
\hline Irregularity of menses & 22 & 5.50 \\
\hline Dyspareunia & 18 & 4.50 \\
\hline Infertility & 32 & 8.00 \\
\hline Others & 18 & 4.50 \\
\hline Multiple responses & 11 & 2.75 \\
\hline Cancer, abortion & 08 & 2.00 \\
\hline $\begin{array}{l}\text { Cancer, abortion, premature } \\
\text { rupture of membrane }\end{array}$ & 04 & 1.00 \\
\hline $\begin{array}{l}\text { Pre-term labour dysmenorrhoea, } \\
\text { dyspareunia, infertility }\end{array}$ & & \\
\hline
\end{tabular}

Table 5: Knowledge regarding HIV prevention among study group $(\mathrm{N}=400)$.

\begin{tabular}{|lll|}
\hline $\begin{array}{l}\text { Knowledge regarding HIV } \\
\text { prevention }\end{array}$ & Frequency & $\%$ \\
\hline No idea & 162 & 40.50 \\
\hline Usage of condoms & 86 & 21.50 \\
\hline Monogamous relationship & 34 & 8.50 \\
\hline Sterile needle usage & 32 & 8.00 \\
\hline Treatment of case and partner & 47 & 11.75 \\
\hline Multiple responses & 22 & 5.50 \\
\hline $\begin{array}{l}\text { Usage of condoms, } \\
\text { monogamous relationship }\end{array}$ & 13 & 3.25 \\
\hline $\begin{array}{l}\text { Usage of condoms, } \\
\text { monogamous relationships, } \\
\text { treatment of case and partner }\end{array}$ & & 1.00 \\
\hline $\begin{array}{l}\text { Usage of condoms, } \\
\text { monogamous relationships, } \\
\text { sterile needle, treatment of case } \\
\text { and partner }\end{array}$ & 4 & \\
\hline
\end{tabular}

Table 6 shows $75.3 \%$ of women reported that treatment was needed for the cure out of them about $24.7 \%$ of women reported that treatment should not be taken for reproductive tract infections because of social $(60 \%)$ and personal reasons $(87 \%)$.
Table 6: Knowledge regarding treatment necessity for reproductive tract infections amongst married women of study group $(\mathrm{N}=400)$.

\begin{tabular}{|lll|}
\hline $\begin{array}{l}\text { Knowledge regarding } \\
\text { treatment necessity }\end{array}$ & Frequency & Percentage \\
\hline Yes & 301 & 75.3 \\
\hline To whom & & \\
\hline Doctor & 176 & 44.0 \\
\hline Nurse & 38 & 9.5 \\
\hline Health workers & 64 & 16.0 \\
\hline Chemist & 10 & 2.5 \\
\hline Self & 6 & 1.5 \\
\hline Others & 7 & 1.8 \\
\hline No & 99 & 24.7 \\
\hline Reasons & & \\
\hline Social reasons & 64 & 16.0 \\
\hline Personal reasons & 35 & 8.7 \\
\hline
\end{tabular}

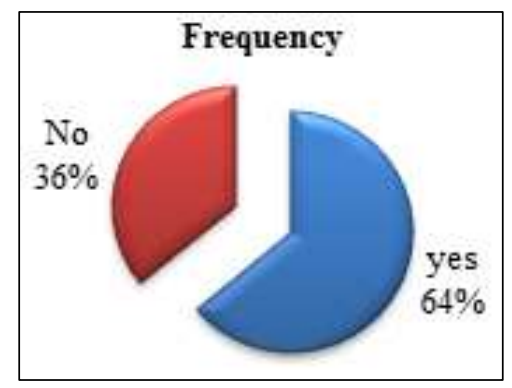

Figure 1: Awareness of disease among reproductive age group of women in the rural area of Surendranagar district $(\mathrm{N}=400)$.

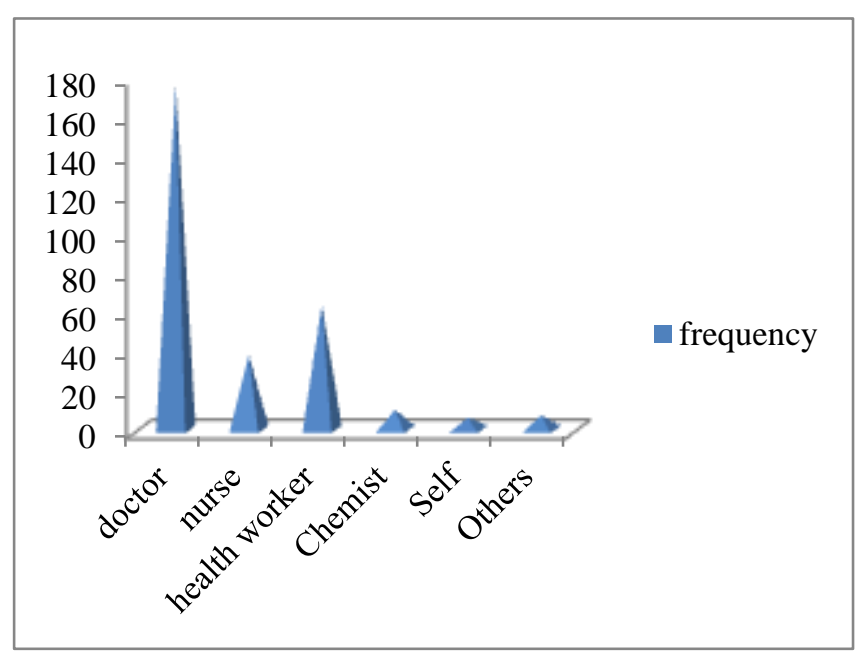

Figure 2: Knowledge of women regarding treatment accessibility for reproductive tract infections. 


\section{DISCUSSION}

Basic awareness was $64.0 \%$; similar studies conducted in Nigeria, rural West Bengal and Kenya were 77.2\%, 57\% and $96 \%$ respectively. ${ }^{3-5}$ In rural Bangladesh was $12 \% .{ }^{6}$ Regarding disease occurrence and transmission $8.5 \%$ of women reported lack of personal hygiene could be cause. A study in Lima Peru; sexual contact, lack of personal hygiene and exposure to the contaminated environment were causes. ${ }^{7}$ A study conducted in Lagos toilet as contracting mode, sexual intercourse and poor hygiene. ${ }^{3}$ In rural Bangladesh; common causes narrated were sexual intercourse, infections and multiple sexual partners. ${ }^{6}$ A study conducted in Karachi; melting bone, consuming food with perceived hot composition, poor personal hygiene and procedures like dilatation and curettage and induced abortions were the reasons. ${ }^{8}$

Regarding symptoms, $(15.8 \%)$ reported backache followed by vaginal discharge, itching, lower abdominal pain, burning micturition, dyspareunia and genital ulcerations. A study conducted in Lagos, Nigeria in which $57.7 \%$ of women reported vaginal discharge followed by vulval itching and lower abdominal pain. ${ }^{3}$ Majority of women narrated dysmenorrhoea as a complication of disease followed by infertility, dyspareunia, premature rupture of membrane. A study in Lagos, Nigeria; $57.5 \%$ of women reported infertility followed by cervical cancer, heavy menses, ectopic pregnancy, chronic pelvic pain, still birth. ${ }^{3}$ Knowledge regarding HIV prevention; $21.50 \%$ of women reported usage of condoms as the way of prevention followed by treatment of case and partner, monogamous relationships and sterile needle usage. $96 \%$ of women were aware of HIV in Western Kenya. ${ }^{5}$

Knowledge regarding treatment necessity, $75.3 \%$ of women said that treatment should be taken. $44 \%$ of women told that treatment should be taken from doctor followed by health workers, nurse, chemist, selftreatment and others like faith healers, homemade remedies etc $(16.0 \%, 9.5 \%, 2.5 \%, 1.8 \%, 1.5 \%)$. A study conducted in Uganda; $60 \%$ of women reported that treatment should be taken from faith healers. ${ }^{10}$

\section{CONCLUSIONS}

Basic awareness about disease was $64.0 \%$. $82.2 \%$ of women narrated one or the other symptom, $42.00 \%$ of women had no idea regarding its complications. Knowledge regarding HIV prevention was $59.50 \%$. Knowledge about treatment necessity, $75.3 \%$ of women narrated that treatment was necessary. Social stigma and personal reasons were obstacles to seeking medical help.

\section{Recommendations}

In view of the result from this study it can be said that we need to have effective strategies for the early diagnosis and treatment of reproductive tract infections and for their prevention, through information education and behavioral change. It can go a long way in controlling the spread of HIV, AIDS also and in reducing reproductive morbidity.

\author{
Funding: No funding sources \\ Conflict of interest: None declared \\ Ethical approval: The study was approved by the \\ institutional ethics committee
}

\section{REFERENCES}

1. Ramesh Chellan, Gynaecological morbidity and treatment seeking behavior in South India: Evidence from the Reproductive and Child Health survey 1998-1999. Available at: http://www.jhpdc.unc.edu.

2. National reproductive tract infections (RTI) policy guidelines (GHS/HRU/HORIZONS/USAID and WHO) 2003. Available at: http://www.ilo.org.

3. Kabiru A. Rabiu, Adeniyi A. Adewunmi, Fatimat M. Akinlusi, and Oluwarotimi I. Akinola. Female reproductive tract infections: understandings and care seeking behavior among women of reproductive age in Lagos, Nigeria. BMC Women Health. 2010;10:8-12.

4. Dawn A, Biswas R. Reproductive tract infection: an experience in rural West Bengal. Indian Journal of Public Health. 2005;49(2):102-3.

5. Wools KK, Menya D, Muli F, Heilman D, Jones R. Perception of risk, sexual behavior and STD/HIV prevalence in Western Kenya. East Africa Medicine Journal. 1998;75(12):679-83.

6. Khan MA, Rahman M, Khanam PA, Barkat-eKhuda, Kane TT, Ashraf A. Awareness of sexually transmitted disease among women and service providers in rural Bangladesh. International Journal of STD/AIDS. 1997;8(11):688-96.

7. Hernandez LS, Winch PJ, Parker K, Gilman RH. Understanding of reproductive tract infections in a peri-urban pueblo joven in Lima Peru. BMC Women's Health. 2006;6(7). doi:10.1186/14726874-6-7.

8. Bhatti LI, Fikree FF. Health seeking behavior of Karachi women with reproductive tract infections. Social Science Medicine. 2002;54:105-17.

9. Sangeetha S. Balamurugan, ND Bendigeri. Community based study of reproductive tract infections among women of reproductive age group in the Urban Health Training Centre Area in Hubli, Karnataka. Indian Journal of Community Medicine. 2012 January-March;37(1):34-8.

10. Muyinda H, Seeley J, Pickering H, Barton T. Social aspects of AIDS-related stigma in rural Uganda. Health Place. 1997;3:143-7.

DOI: $10.5455 / 2320-1770 . i j \mathrm{rcog} 20140319$

Cite this article as: Thekdi KP, Mehta P, Thekdi

$\mathrm{PI}$. Awareness regarding reproductive tract

infections among married women in the rural area of Surendranagar. Int J Reprod Contracept Obstet Gynecol 2014;3:98-101. 